\title{
MANAJEMEN SIARAN PENDIDIKAN DI PROGRAMA 1 (SATU) RADIO REPUBLIK INDONESIA (RRI) PEKANBARU
}

\author{
Dwiva Devi Shintia ${ }^{1)}$ \\ Azhar ${ }^{2)}$ \\ Hadriana ${ }^{3)}$ \\ ${ }^{1)}$ Post Graduate Student of Riau University \\ ${ }^{2)}$ Lecturer of Education Management Study Programme PPs University of Riau \\ ${ }^{3)}$ Lecturer of Education Management Study Programme PPs University of Riau
}

\begin{abstract}
The purpose of this study to describe and analyze the Management of Educational Broadcast inPrograma 1 (one) Radio Republik Indonesia (RRI) Pekanbaru viewed from the management functions of planning, organizing, actuating, and controlling. This study used descriptive qualitative method. Data collection was done by observation, interview, and documentation. The analysis technique used in this research is by Miles and Huberman method (1992) that is through data reduction process, data presentation, conclusion and triangulation.The results of the study show that the Education Broadcasting Management in Programa 1 (one) Radio Republik Indonesia (RRI) Pekanbaru has been running well. The first step of planning is a program that runs every year to create educational programs. Next determine the educational broadcast team, broadcaster, educational theme, broadcast schedule and resource person. Resource persons are carefully selected to provide accurate information. Planning in the studio engineering section is done matrang by providing guidance to the lookbook given to the broadcaster as a guide during the broadcast. Organizing educational broadcast in Programa 1 (one) RRI Pekanbaru is done by forming Team by Head of LPP RRI Pekanbaru prepared at the time of program of yearly program or have according to SK respectively if status of civil servant and given authority with clear job description. Implementation of education broadcast In Programa 1 (one) RRI Pekanbaru has been implemented in accordance with Government Regulation of the Republic of Indonesia Number 12 Year 2015 on Radio Public Broadcasting Institution of the Republic of Indonesia and KPI regulations on Broadcasting Conduct Manual (P3) of 2012. Supervision in RRI All Indonesia is conducted by Supervisory Board The highest position in RRI. RRI Pekanbaru supervision conducted by the Head of LPP RRI Pekanbaru. For the supervision of the broadcast program conducted by the head of broadcast program with the head of the planning and evaluation section of the program in Programa 1 (one) Pekanbaru conducted by Section Head of Programa 1 (one).
\end{abstract}

\section{Key words: Broadcast management, educational broadcast, Radio Republik Indonesia}

ABSTRAK:Penelitian ini bertujuan untuk mendeskripsikan dan menganalisis Manajemen Siaran Pendidikan di Programa 1 (satu) Radio Republik Indonesia (RRI) Pekanbaru ditinjau dari fungsifungsi manajemen yaitu perencanaan, pengorganisasian, pelaksanaan, dan pengawasan. Penelitian ini menggunakan metode deskriptif kualitatif.Pengumpulan data dilakukan dengan metode observasi, wawancara, dan dokumentasi. Teknik analisis yang digunakan dalam penelitian ini adalah dengan metode Miles dan Huberman (1992) yaitu melalui proses reduksi data, penyajian data, penarikan kesimpulan serta triangulasi. Hasil peneltian menunjukkan bahwa Manajemen Siaran Pendidikan di Programa 1 (satu) Radio Republik Indonesia (RRI) Pekanbaru sudah 
berjalan dengan baik. Langkah awal perencanaan adalah melalui rapat program yang dilaksanakan setiap tahun untuk membuat program pendidikan. Selanjutnya menentukan tim siaran pendidikan, penyiar, tema pendidikan, jadwal siaran dan narasumber. Narasumber dipilih dengan seksama yang dapat memberikan informasi yang akurat. Perencanaan di bagian teknik studio dilakukan secara matrang dengan cara memberikan panduan berupa lookbook yang diberikan kepada penyiar sebagai pedoman pada saat siaran. Pengorganisasian siaran pendidikan di Programa 1 (satu) RRI Pekanbaru dilakukan dengan membentuk Tim oleh Kepala LPP RRI Pekanbaruyang direncanakan pada saat rapat program tahunan atau telah sesuai dengan SK masing-masing jika berstatus PNS dan diberikan wewenang dengan uraian tugas yang jelas.Pelaksanaan siaran pendidikan di Programa 1 (satu) RRI Pekanbarusudah dilaksanakan berdasarkan Peraturan Pemerintah Republik Indonesia Nomor 12 Tahun 2015 tentang Lembaga Penyiaran Publik Radio Republik Indonesia serta peraturan KPI tentang Pedoman Perilaku Penyiaran (P3) tahun 2012. Pengawasan di RRI seluruh Indonesia dilakukan oleh Dewan Pengawas yang merupakan jabatan tertinggi di RRI. Sedangkan pengawasan RRI Pekanbaru dilakukan oleh Kepala LPP RRI Pekanbaru.Untuk pengawasan program siaran dilakukan oleh kepala bidang program siaran bekerjasama denga kepala seksi perencanaan dan evaluasi programa sedangkan pengawasan jadwal siaran di Programa 1 (satu) Pekanbaru dilakukan oleh Kepala Seksi Programa 1 (satu).

Kata Kunci: Manajemen siaran, siaran pendidikan, Radio Republik Indonesia

\section{PENDAHULUAN}

Pendidikan merupakan salah satu sector penting dalam pembangunan di setiap negara. Menurut Undang-Undang No. 20 Tahun 2004, pendidikan merupakan usaha sadar dan terencana untuk mengembangkan segala potensi yang dimiliki peserta didik melalui proses pembelajaran. Pendidikan bertujuan untuk mengembangkan potensi anak agar memiliki kekuatan spiritual keagamaan, pengendalian diri, berkepribadian, memiliki kecerdasan, berakhlak mulia, serta memiliki keterampilan yang diperlukan sebagai anggota masyarakat dan warganegara.

Pendidikan dapat diperoleh melalui pendidikan formal dan pendidikan non formal. Pendidikan formal dapat diperoleh anak di sekolah sedangkan pendidikan non formal diperoleh anak di luar sekolah. Pendidikan non formal juga dapat diperoleh melalui media massa. Dengan media, khususnya dibidang komunikasi yang terbukti telah banyak membantu manusia dalam bertukar pengalaman dan pemikiran dalam volume yang relatif besar tanpa harus bertatap muka dan menempuh perjalanan jauh yang memakan waktu, dan dapat ditransfer dengan waktu yang sangat cepat tanpa terbatas jarak.

Radio merupakan sarana komunikasi massa yang banyak manfaatnya. Disamping bermanfaat sebagai media hiburan, informasi, dan kontrol sosial, radio juga dapat digunakan sebagai salah satu media pendidikan. Namun, keberadaan program siaran pendidikan di radio masih sangat terbatas karena sangat kecil persentasenya dibanding dengan program siar lainnya. Berdasarkan survey Nielsen 2014, tiap tahun, pendengar radio mengalami penurunan hingga $3 \%$. Sedangkan dalam sebagai media promosi, radio hanya memiliki porsi penetrasi $30 \%$ penggunaan di tengah masyarakat, dibanding televisi, majalah dan media lainnya. Penyelenggara radio yang ada di Indonesia kini semakin beragam dan terus meningkat dengan segmentasi dan tata kelola yang bervariasi untuk mencapai hasil yang optimal guna kepuasan khalayak pendengar. Oleh karena itu, industri media siaran radio selayaknya dikelola dengan konsep yang memadai khususnya bagi siaransiaran pendidikan yang mampu menjadi sumber belajar masyarakat dari segala segmen.

Salah satu radio yang menyuguhkan program pendidikan adalah Radio Republik 
Indonesia (RRI). Radio Republik Indonesia (RRI) adalah satu-satunya stasiun radio yang dimiliki oleh Negara Kesatuan Republik Indonesia (NKRI). Radio ini memiliki slogan "sekali mengudara, tetap mengudara”, slogan dari radio ini dapat terwujud hingga saat ini, dimana sekarang RRI masih tetap mengudara.

Peran RRI sampai saat ini sangat jelas selain membantu menyampaikan program-program pemerintah kepada masyarakat, RRI tentunya sangat berperan membantu menjaga stabilitas NKRI dengan memberikan informasi yang mendidik dan cerdas mengenai tema-tema kebangsaan, nasionalisme, pendidikan, dan kebudayaan. Peran RRI dalam bidang pendidikan sendiri diatur pada Pasal 4 Bagian Ketiga Peraturan Pemerintah Republik Indonesia Nomor 12 Tahun 2005 tentang Lembaga Penyiaran Publik Radio Republik Indonesia.

RRI Pekanbaru mempunyai 4 programa yaitu: Programa 1 mengudara pada frekuensi 99,1 Mhz, Programa 2 untuk segmen remaja, sasaran khalayak usia 20-39 tahun, sasaran wilayah dan kota sekitarnya, untuk status sosial menengah keatas yang mengudara pada frekuesi 88,4 Mhz. Sedangkan programa 3 yang mengudara pada frekuensi 91,2 Mhz sasaran khalayaknya Usia 30-45tahun dan pendidikan SLTA ke atas, sasaran wilayah yaitu kota dan pedesaandan status sosial semua merata. Siaran pro 3 di khususkan langsung dariJakarta dan programa 4 yang mengudara di 95,9 Mhz. (Radio RRI,Company Profile,2016).

Dengan adanya program pendidikan yang ada di RRI, memudahkan seseorang untuk belajar dimana saja dan kapan saja. Siaran pendidikan di RRI juga tidak terhambat oleh kemampuan baca dan tulis khalayak. Tetapi program pendidikan yang ada di RRI juga mempunyai keterbatasan seperti keterbatasan interaksi, tidak dapat ditinjau dan waktu untuk refleksi pada konten minimal. Selain itu juga, banyak khalayak, terutama anak yang masih sekolah, yang lebih suka menonton hiburan yang ada di televisi daripada mendengarkan radio. Keterbatasan ini juga harus terus diupayakan solusinya. Salah satu caranya adalah dengan meninjau dari aspek manajemen di salah satu programa yang ada di RRI.

Manajemen merupakan suatu prosesperencanaan, pengorganisasian, Pelaksanaan dan pengawasan dari subunitsubunit organisasi serta penggunaan segala sumber daya yang ada dalam suatu organisasi agar mampu secara optimal mencapai tujuan dari organisasi yang telah digariskan.Aktivitas manajemen mutlak harus dilakukan, demi kelangsungan hidup suatu organisasi, termasuk organisasi radio siaran. Dengan adanya sistem manajemen dalam organisasi maka upaya pencapaian tujuan dari organisasi dapat dicapai dengan sistematis dan optimal.

Berdasarkan uraian latar berlakang di atas, maka peneliti bermaksud mengungkap "Manajemen Siaran Pendidikan di Programa 1 (satu)Radio Republik Indonesia (RRI) Pekanbaru."

Secara terminology, kata manajemen menurut GR. Terry (dalam Malayu S.P Hasibuan,2007) adalah sebuah proses yang khas, terdiri dari tindakan-tindakan perencanaan, pengorganisasian, pelaksanaan dan pengawasan yang dilakukan untuk menentukan serta mencapai sarana-sarana yang telah ditetapkan melalui pemanfaatan sumber daya manusia serta sumber-sumber lainnya.

Siaran menurut kamus umum Bahasa Indonesia adalah sesuatu yang disiarkan. Siaran berasal dari kata siar yang berarti menyebarluaskan informasi melalui pemancar. Pengertian manajemen penyiaran menurut J.B Wahyudi (2008) adalah kemampuan seseorang untuk mempengaruhi/memanfaatkan kepandaian/ keterampilan orang lain untuk merencanakan, memproduksi, dan menyiarkan siaran dalam usaha mencapai tujuan bersama.Menurut Wahyudi (2008) dalam bukunya "Dasar-dasar manajemen penyiaran", pendekatan manajemen menggunakan teori "input-output model” dari Henry Fayol dan Frederick Taylor, sedangkan pendekatan penyiaran menggunakan teori "komunikasi matematika" dari Shannon dan Weaver. Melalui dua teori di atas, Wahyudi menjelaskan akan terjadi proses manajemen 
penyiaran di atas landasan pengimpitan prinsipprinsip dasar manajemen dan prinsip-prinsip dasar penyiaran yang berorientasi pada tujuan yang hendak dicapai melalui terciptanya siaran yang berkualitas, baik dan benar.

Agar dapat mencapai tujuannya, manajemen memerlukan adanya sarana-sarana atau alat-alat. Tanpa adanya unsur-unsur tersebut manajemen tidak akan tercapai. Sarana manajemen dapat dirumuskan dalam $6 \mathrm{M}$ (Suwardi Hardaningrat, 2011) yaitu :

1) Men ( sumber daya manusia), seorang yang bekerja di dunia penyiaran, tidak cukup hanya menguasai teori terapi juga harus dipraktekkan. Perpaduan antara teori komunikasi dan praktek dalam memproduksi dan menyiarkan program acara, akan meningkatkan kreativitas seseorang yang berkecimpung di dunia penyiaran untuk menciptakan program yang layak.

2) Money ( kemampuan keuangan), uang adalah sumber yang paling pokok dalam suatu penyiaran.

3) Methods (cara atau sistem yang digunakan untuk mencapai tujuan

4) Materials (bahan-bahan yang dikuasai), bahan-bahan yang diperlukan dalam proses penyiaran radio adalah macam-macam bentuk bentuk penyajian acara yang dimiliki oleh stasiun-stasiun radio.

5) Machine (alat atau perkakas mesin yang dimiliki), pada dasarnya proses berlangsungnya siaran radio hanya memerlukan beberapa peralatan, yaitu : Microphone, Ampliphier, dan Transmitter.

6) Market (tempat untuk melempar hasil atau menjual produksi atau karya), peran radio yang paling penting adalah sebagai alat untuk memproyeksikan identitas, karena dengan identitas inilah radio dapat menarik seorang pendengar.

Kegiatan yang dilakukan oleh manajemen dalam sistem penyiaran (televisi/radio) meliputi sebagai berikut :

\section{1) Perencanaan (planning)}

Perencanaan menurut Richard L. Daft (2010) berarti mengidentifikasikan berbagai tujuan untuk kinerja organisasi di masa mendatang serta memutuskan tugas dan penggunaan sumber daya yang diperlukan.

Menurut JB Wahyudi (2008) dalam dunia penyiaran, perencanaan merupakan unsur yang sangat penting, karenasiaran memiliki dampak yang sangat luas di masyarakat.

Dalam merencanakan, perencanaan siaran harus mempunyai variabel-variabel yang harus dipertimbangkan dalam perencanaan di radio atau televisi (Morisson,2011) yaitu :

a. Idealisme, merupakan visi dan misi dari lembaga penyiaran tersebut yang dioperasionalkan dalam tujuan penyiaran.

b. Orientasi bisnis dengan mengacu pada program-program atau acara-acara yang dapat mempunyai rating tinggi.

c. Orientasi khalayak adalah mencakup kebutuhan khalayak dan keinginan khayalak. Perbedaannya antara keinginan dan kebutuhan khalayak dilihat dari segi formating acara. Jika information (informasi) merupakan kebutuhan khalayak, entertainment (hiburan) adalah keinginan masyarakat.

\section{2) Pengorganisasian (organizing)}

Pengorganisasian merupakan proses penyusunan struktur organisasi yang sesuai dengan tujuan organisasi, sumber daya yang dimiliki dan lingkungan yang melingkupinya. Dua aspek utama proses penyususan struktur organisasi adalah departementalisasi dan pembagian kerja. Departementalisasi merupakan pengelompokan kegiatan-kegiatan kerja suatu organisasi agar kegiatan yang sejenis dan saling berhubungan dapat dikerjakan bersama (Morissan, 2008).

Struktur organisasi stasiun penyiaran pada umumnya tidak memiliki standar yang baku. Bentuk organisasi stasiun penyiaran berbedabeda satu dengan lainnya, bahkan pada wilayah yang sama tidak miliki struktur organisasi yang 
persis sama. Perbedaan biasanya disebabkan oleh skala usaha atau besar kecilnya stasiun penyiaran.

Pada stasiun kecil atau menengah mungkin ada beberapa jabatan atau fungsi manajerial yang dirangkap oleh satu orang. Misalnya, general manager yang bisa juga menjadi manajer pemasaran, manajer program dapat juga menjadi manajer operasi, manajer operasi dapat juga menjadi manajer teknik. Sementara untuk stasiun besar biasanya, ada posisi manjer senior untuk setiap departemen.

Menurut Willias danAldridge (1991) stasiun penyiaran umumnya memiliki empat fungsi dasar (areas of operation) dalam struktur organisasinya yaitu teknik, program, pemasaran dan administrasi.Fungsi pertama hingga ketiga tersebut menjadi pilar utama stasiun penyiaran. Sebagaimana sebuah bangunan , maka ketiga fungsi tersebut merupakan tiang atau pilar yang menopang bangunan stasiun penyiaran, jika salah satu tidak ada atau roboh, maka robohlah stasiun penyiaran itu. dengan kata lain, tanpa ketiga tersebut tidak mungkin suatu stasiun penyiaran dapat berdiri dan bertahan. Sedangkan fungsi administasi dalah fungsi pendukung guna memperlancar tugas dari ketiga sebelumnya.

\section{3) Pelaksanaan (actuating)}

Menurut G.R. Terry (1996), pelaksanaan (actuating) adalah usaha untuk menggerakkan semua anggota kelompok kerja agar mau bekerjasama untuk mencapai sasaran-sasaran yang sesuai dengan perencanaan dan usahausaha pengorganisasian. Pelaksanaan atau pelaksanaan menurut JB.Wahyudi (2008) mencakup perencanaan pemrograman, produksi, dan penyiaran. Pada tahap ini peran manajer sangat penting untuk dapat menggerakkan semua elemen-elemen yang ada sesuai dengan fungsi dan tugasnya.

Efektivitas mengudaranya sebuah program ditentukan oleh orientasi manajer yang memimpin, memotivasi, mengkoordinasi, memfasilitasi serta adanya komunikasi pada staf-stafnya untuk bekerjasama dalam mencapai tujuan.

\section{a. Kepemimpinan (Leadership)}

Kepemimpinan adalah suatu proses pemberian pengaruh dan pengarahan dari seorang pemimpin terhadap orang lain (atau sekelompok orang) untuk melakukan suatu aktifitas tertentu yang sesuai kehendaknya (Abdulsyani,1987).

\section{b. Komunikasi}

Komunikasi sebagai proses pemegang peranan penting untuk menciptakan iklim kerja harmonis dan menciptakan kreadibilitas organisasiterhadap masyarakat lingkungan. Komunikasi merupakan kebutuhan hakiki umat manusia. Manusia akan sukses dalam hidupnya jika pandai memilih strategi komunikasi secara tepat dalam menghadapi permasalahan, bahkan manusia menjaga kreadilibilitas diri melalui proses komunikasi.

\section{c. Motivasi}

Motivasi merupakan dorongan yang diberikan oleh atasan kepada bawahannya.Setiap kegiatan pasti ada tujuan yang ingin dicapai.Tujuan pemberian motivasi adalah untuk memberikan dorongan gairah dan semangat kerja karyawan, meningkatkan produktivitas kerja dan kepuasan kerja karyawan dan lain sebagainya.

\section{d. Fasilitas}

Ketiga unsur diatas tidak akan sempurna jika tidak mempunyai fasilitas karena fasilitas kerja yang memadai dapat mewujudkan prestasi kerja yang tinggi.Seiring dengan perkembangan zaman serta semakin canggihnya teknologi informasi, maka fasilitas untuk proses penyiaran radio perlu diadakan penyegaran dalam pembaharuan mesin. Hal ini perlu dilakukan agar dapat meningkatkan kualitas siaran serta mampu memberikan imbalan yang layak kepada para pelaksana sesuai dengan karya yang dihasilkan.

\section{4) Pengawasan (controlling)}

Pengawasan berarti memonitor aktivitas karyawan, menentukan apakah organisasi sejalan dengan tujuannya dan membuat koreksi jika diperlukan (Richard L. Daft, 2010). 
Proses pengawasan dan evaluasi menentukan seberapa jauh suatu rencana dan tujuan sudah dapat dicapai atau diwujudkan oleh stasiun penyiaran, departemen dan karyawan. Kegiatan evaluasi secara periodik terhadap masing-masing individu dan departemen masingmasing dan departemen memungkinkan manajer umum membandingkan kinerja sebenarnya dengan kinerja yang direncanakan.

Proses dasar pengawasan ada tiga tahap (JB Wahyudi, 2008) yaitu:

a. Menyusun standar kerja (standar operating procedure dan petunjuk pelaksanaan kerja)

b. Ukuran pelaksanaan atas dasar standar yang ada

c. Melakukan koreksi pada standar dan perencanaan.

\section{METODOLOGI PENELITIAN \\ Pendekatan Penelitian}

Metode yang digunakan dalam penelitian ini ialah metodepenelitian deskriptif kualitatif. Mulyana (2001) mengungkapkan metode penelitian kualitatif merupakan metode penelitian yang tidak mengandalkan bukti berdasarkan logika matematis, prinsip, angka, atau metode statistik.

\section{Subjek dan Objek Penelitian}

Adapun yang menjadi subjek penelitian ini adalah koordinator (kepala bidang dan kepala seksi), semua crew, dan lainnya yang dianggap memiliki peranan penting dalam manajemen siaran pendidikan di programa 1 (satu).

Objek penelitian adalah sesuatu yang ingin diteliti atau data apa yang ingin dikumpulkan. Objek dalam penelitian ini adalah manajemen siaran pendidikan di Radio Republik Indonesia (RRI) pada programa 1 yang dimulai dari perencanaan, pengorganisasian, pelaksanaan, sampai pada tahap pengawasan.

\section{Teknik Pengumpulan Data}

Teknik yang digunakan peneliti dalam mengumpulkan data adalah sebagai berikut :

\section{1) Observasi}

Menurut Arikunto (2010) observasi adalah suatu usaha sadar untuk mengumpulkan data yang dilakukan secara sistematis dengan prosedur standar.

Dalam penelitian ini, peneliti menggunakan metode observasi non-partisipan, yang hanya mengamati dan mencatat segala sesuatu yang berhubungan dengan manajemen siaran pendidikan di RRI pada programa 1 (satu) tanpa terlibat langsung di dalamnya. Data yang diobservasi oleh peneliti untuk mendapatkan data perencanaan, pengorganisasian, Pelaksanaan, dan pengawasan siaran pendidikan di RRI pada programa 1 (satu).

\section{2) Wawancara (interview)}

Wawancara adalah bentuk komunikasi antara dua orang, melibatkan seseorang yang ingin memperoleh informasi dari seseorang dengan mengajukan pertanyaan- pertanyaan berdasarkan tujuan tertentu (Mulyana, 2001).

Pada penelitian ini, terdapat 2 (dua) jenis narasumber yang akan akan diwawancarai, yaitu narasumber primer, merupakan pihak-pihak yang bertindak sebagai fokus utama dalam wawancara dan dapat memberikan informasi yang diperlukan tentang objek yang diteliti. Kepala Seksi Perencanaan dan Evaluasi Programa, Kepala Seksi Pro 1, staf bagian siaran Pro 1, serta Staf Bagian Teknik di RRI sebagai narasumber primer.

Selain itu penelitian juga akan mewawancarai narasumber sekunder sebagai pelengkap yang membantu peneliti untuk memahami objek yang akan diteliti. Dalam hal ini yang akan menjadi narasumber sekunder adalah para pendengar siaran pendidikan Pro 1 di RRI.

\section{3) Dokumentasi}

Metode ini adalah mengumpulkan data melalui peninggalan tertulis, terutama berupa arsip-arsip dan termasuk juga buku-buku tentang pendapat, teori, dalil/hukum-hukum, dan lain-lain yang berhubungan dengan masalah penyelidikan.

Teknik ini merupakan cara mengumpulkan data sekunder berupa dokumen penting yang 
berhubungan dengan data sumber penelitian ini dan juga gambaran umum tentang RRI, berupa arsip, foto, transkip acara radio dan lainnya yang mendukung penelitian ini.. Data yang ingin diperoleh oleh peneliti berdasarkan dokumentasi adalah bagaimanaperencanaan, pengorganisasian dan pelaksanaan siaran pendidikan di RRI pada programa 1.

\section{Teknik Analisis Data}

Teknik analisis yang digunakan dalam penelitian ini adalah dengan menggunakan model Miles dan Huberman (1992) yaitu melalui proses reduksi data, penyajian data, penarikan simpulan serta triangulasi. Adapun penjabaran analisis data tersebut adalah sebagai berikut:

\section{1) Data Reduction (Reduksi Data)}

Reduksi Data merupakan suatu proses pemilihan, pemusatan perhatian pada penyederhanaan, pengabstrakan, dan transformasi data awal yang muncul dari catatancatatan tertulis di lapangan. Reduksi data ini berlangsung secara terus menerus selama penelitian kualitatif berlangsung.

\section{2) Data Display (Penyajian Data)}

Pada tahap ini, peneliti mengembangkan sebuah deskripsi informasi tersusun untuk menarik kesimpulan dan pengambilan tindakan. Penyajian data yang lazim digunakan dalam penelitian ini adalah bentuk teks naratif.

\section{3) Conclusion/ Verying (Penarikan Kesimpulan)}

Tahap ini adalah adalah tahap pengambilan keputusan atau penarikan kesimpulan hanyalah sebagian dari kegiatan dari kongfigurasi yang utuh. Kesimpulan-kesimpulan juga diverifikasi selama penelitian langsung.

\section{4) Triangulasi}

Triangulasi adalah teknik pemeriksaan data untuk keperluan pengecekan atau sebagai pembanding terhadap data yang telah diperoleh. Pada penelitian ini, peneliti akan menggunakan triangulasi sumber dan triangulasi teknik.
Triangulasi sumber adalah pengecekan data yang dilakukan dengan cara mengecek data yang telah diperoleh melalui beberapa sumber. Dalam penelitian ini, untuk memperoleh data mengenai manajemen di RRI Programa 1 Pekanbaru, maka pengumpulan dan pengujian data yang telah diperoleh dilakukan ke staf RRI sebagai objek peneltian.

Triangulasi Teknik adalah teknik pengecekan data yang dilakukan denngan cara mengecek data kepada sumber yang sama dengan teknik yang berbeda. Dalam penelitian ini, peneliti memperoleh data dengan wawancara, kemudian dicek dengan observasi dan dokumentasi.

\section{HASIL PENELITIAN}

Temuan penelitian dirangkum berdasarkan hasil observasi, dokumentasi dan wawancara dengan pihak RRI Pekanbaru.Data yang digunakan dalam penelitian ini adalah data tahun 2016 semester 2 (dua). Temuan penelitian diuraikan menurut Subfokus penelitian adalah sebagai berikut :

\section{Subfokus 1 :Perencanaan Siaran Pendidikan di Programa 1(satu) RRI Pekanbaru}

Perencanaan siaran pendidikan di Programa 1(satu) RRI Pekanbaru dimulai dari perencanaan tim. RRI Pekanbaru merupakan stasiun tipe B. Berdasarkan dokumentasi dengan bagian SDM, Pegawai PNS yang bekerja di RRI diangkat oleh Pemerintah berdasarkan Undang-Undang yang berlaku sedangkan Pegawai Bukan PNS (PBPNS) diangkat oleh Dewan Direksi melalui perjanjian kerja.Setiap Programa di RRI Pekanbaru sendiri mempunyai Kepala Seksi, yang langsung dibawahi oleh Kepala Bidang Program Siaran. Pada setiap programa juga mempunyai Penanggung Jawab Teknik, Marketing, Program Director , dan Administrasi Siaran. Program Director membawahi Music Director dan Koordinator Announcer (penyiar) yang bestatus PNS maupun PBPNS.

Selanjutnya perencanaan yang harus diperhatikan adalah perencanaan program siaran.Rancangan materi program siaran yang 
terdapat di RRI haruslah sesuai dengan visi dan misi RRI serta sesuai dengan Pedoman Perilaku Penyiaran (P3) dan Standard Program Siaran (SPS) yang diterbitkan oleh Komisi Penyiaran Indonesia. Berikut adalah pengamatan yang dilakukan oleh peneliti dan wawancara dengan pendengar terhadap rancangan materi program pendidikan di RRI Pekanbaru.

Tabel 2

Rancangan Program Siaran Pendidikan Pro 1 Pekanbaru

\begin{tabular}{|c|c|c|}
\hline $\begin{array}{l}\mathbf{N} \\
\mathbf{o}\end{array}$ & $\begin{array}{l}\text { Kriteria/ } \\
\text { Standar } \\
\text { Objektif }\end{array}$ & Ket \\
\hline 1 & $\begin{array}{l}\text { Format, konten, } \\
\text { konsep atau } \\
\text { kemasan } \\
\text { program sesuai } \\
\text { dengan target } \\
\text { pendengar }\end{array}$ & Memenuhi \\
\hline 2 & $\begin{array}{l}\text { Memperhatikan } \\
\text { kepentingan anak } \\
\text { dalam setiap } \\
\text { aspek produksi } \\
\text { siaran }\end{array}$ & Memenuhi \\
\hline 3 & $\begin{array}{l}\text { Program berisi } \\
\text { pendidikan yang } \\
\text { bermanfaat atau } \\
\text { memiliki dampak } \\
\text { positif bagi } \\
\text { pelajar dan } \\
\text { pendengar lainnya }\end{array}$ & Memenuhi \\
\hline 4 & $\begin{array}{l}\text { Tidak } \\
\text { mengandung } \\
\text { unsur SARA }\end{array}$ & Memenuhi \\
\hline 5 & $\begin{array}{l}\text { Siaran } \\
\text { pendidikan untuk } \\
\text { anak pra sekolah } \\
\text { tidak } \\
\text { mengandung } \\
\text { unsur kekerasan, } \\
\text { seksualitas, } \\
\text { adegan yang } \\
\text { terkait dengan } \\
\text { hal-hal mistis, } \\
\text { muatan yang } \\
\text { mendorong anak } \\
\text { melakukan } \\
\text { perilaku yang } \\
\text { tidak pantas. }\end{array}$ & Memenuhi \\
\hline
\end{tabular}

Sejalan dengan program, perencanaan jadwal siaran harus disesuaikan secara matang.Berdasarkan dokumentasi dan observasi dari peneliti, Jadwal Siaran pendidikan di Programa 1 (satu) RRI Pekanbaru sudah sesuai dengan Pedoman Perilaku Penyiaran (P3) dan Standard Program Siaran (SPS). Diantara Siaran pendidikan di Pro 1 Pekanbaru, target pendengar pendidikan banyak untuk pendidikan khalayak umum. Untuk pendengar umum, jadwal siaran disesuaikan dengan pendengar, contohnya adalah program Jendela Kita (Jelita) yang disiarkan setiap hari. Program ini adalah pendidikan yang dikhususkan untuk keluarga atau wanita yang bekerja sebagai ibu rumah tangga. Pada pukul $10.00 \mathrm{~s} / \mathrm{d} 11.00$, biasanya ibu rumah tangga aktif dalam melihat televisi ataupun mendengar radio.

Persyaratan khusus yang tedapat dalam Pedoman Perilaku Penyiaran (P3) dan Standard Program Siaran(SPS) adalah untuk menentukan jadwal siaran pendidikan bagi anak pra sekolah. Aturan ini terdapat pada Bab 10 pasal 35. Pada pasal ini dijelaskan bahwa Program Siaran yang ditujukan untuk anak usia pra sekolah ditayangkan antara pukul $07.00 \mathrm{~s} / \mathrm{d} 09.00 \mathrm{dan}$ antara pukul 15.00 hingga pukul 18.00 Waktu Indonesia setempat.

Sebagai Radio dibawah pemerintahan, RRI juga dituntut untuk mempunyai sarana dan prasarana yang memadai.Berikut adalah observasi yang dilakukan oleh peneliti tentang sarana prasarana yang ada di RRI Pekanbaru.

Tabel 3

Tabel Sarana dan Prasarana

\begin{tabular}{c|l|c}
\hline No & \multicolumn{1}{|c}{$\begin{array}{c}\text { Sarana dan } \\
\text { Prasarana }\end{array}$} & $\begin{array}{c}\text { Ju } \\
\text { mla } \\
\mathbf{h}\end{array}$ \\
\hline 1 & $\begin{array}{l}\text { Ruang Kepala LPP } \\
\text { RRI }\end{array}$ & 1 \\
\hline 2 & $\begin{array}{l}\text { Ruangan Kepala dan } \\
\text { Staf Bidang }\end{array}$ & 21 \\
\hline 3 & Ruang Editing & 1 \\
\hline 4 & $\begin{array}{l}\text { Ruang Siaran } \\
\text { (studio) }\end{array}$ & 3 \\
\hline 5 & Ruang Rekaman & 1 \\
\hline 6 & $\begin{array}{l}\text { Ruangan membuat } \\
\text { berita }\end{array}$ & 1 \\
\hline 7 & Aula & 1 \\
\hline 8 & WC & 9 \\
\hline 9 & Gudang & 1 \\
\hline 10 & Ruang Rapat & 2 \\
\hline
\end{tabular}


Tabel 4

Sarana dalam studio

\begin{tabular}{c|c|c|c}
\hline No & Sarana & Rasio & $\begin{array}{c}\text { Ada/ } \\
\text { Tidak }\end{array}$ \\
\hline 1 & Microphone & $\begin{array}{c}6 \\
\text { buah/ruang }\end{array}$ & Ada \\
\hline 2 & Headphone & $\begin{array}{c}4 \\
\text { buah/ruang }\end{array}$ & Ada \\
\hline 3 & Audio mixer & $\begin{array}{c}1 \\
\text { buah/ruang }\end{array}$ & Ada \\
\hline 4 & Komputer & $\begin{array}{c}4 \\
\text { buah/ruang }\end{array}$ & Ada \\
\hline 5 & $\begin{array}{c}\text { Telepon } \\
\text { hybrid }\end{array}$ & $\begin{array}{c}2 \\
\text { buah/ruang }\end{array}$ & Ada \\
\hline 6 & Alat MCR & $\begin{array}{c}1 \\
\text { buah/ruang }\end{array}$ & Ada \\
\hline 7 & Speaker & $\begin{array}{c}1 \\
\text { buah/ruang }\end{array}$ & Ada \\
\hline
\end{tabular}

Narasumber merupakan salah satu unsur penting berjalannya suatu program pada radio.Berdasarkan hasil wawancara dengan Kepala Seksi Programa 1 Pekanbaru, untuk meminta narasumber, biasanya staf Radio Republik Indonesia (RRI) Pekanbaru akan menyurati suatu instansi/lembaga terlebih dahulu dan membero topik apa yang akan dibahas. Biasanya instansi akan menunjuk orang yang sangat memahami mengenai topik yang akan dibahas. Selanjutnya narasumber akan mengkonfirmasi kesediaannya untuk menjadi narasumber.

Perencanaan terakhir yang tidak kalah penting adalah perencanaan bagian teknik. Perencanaan Bagian Teknik, dibagi lagi menjadi beberapa bagian, yaitu Studio dan Media, Teknik Transmisi dan Media, serta Teknik Sarana dan Prasarana Penyiaran. Bagian teknik yang menangani peralatan dan terlaksananya siaran di studio dilaksanakan oleh bagian studio dan media.Berdasarkan hasil wawancara dengan salah satu staf di bagian Teknik menyatakan bahwa terdapat panduan lookbook yang akan disiapkan untuk siaran. Panduan tersebut diberikan kepada penyiar sebagai pedoman pada saat siaran,
Subfokus 2 :Pengorganisasian Siaran Pendidikan Programa 1 (satu) RRI Pekanbaru

Pengorganisasian adalah fungsi kedua dari manajemen program siaran pendidikan di programa 1(satu) RRI Pekanbaru. Pengorganisasian merupakan melibatkan orangorang di dalam suatu kelompok, sumber daya yang dimiliki, dan lingkungan yang melingkupinya.

Radio Republik Indonesia Pekanbaru dipimpin oleh Kepala LPP RRI.Selanjutnya ada kepala bagian tata usaha, kepala bidang program siaran, kepala bidang pemberitaan, kepala bidang teknologi dan media baru serta kepala bidang layanan dan pengembangan usaha yang dibawah langsung oleh Kepala LPP RRI.Dalam tugas penyiaran siaran pendidikan di Programa 1 (satu) Pekanbaru dipimpin oleh kepala seksi programa 1 (satu) yang mana beliau bertanggung jawab terhadap kepala bidang program siaran.Untuk pemilihan penyiar, Kepala Seksi masing-masing programa bertanggung jawab dalam hal ini.

Berdasarkan hasil dokumentasi dan wawancara oleh peneliti, pengorganisasian programa 1(satu) RRI Pekanbaru dilakukan oleh Kepala Bidang Program siaran yang bertanggung jawab dalam atas semua siaran pada semua program. Perencanaan dan evaluasi programa pada seluruh programa dilakukan oleh Kepala Seksi Perencanaan dan Evaluasi Program, sedangkan kepala seksi programa 1 hanya bertanggung jawab untuk mengawasi acara siaran yang ada di programa 1 termasuk siaran pendidikan.

Pengorganisasian Jadwal Siaran Pendidikan khususnya programa 1(satu) ditangani langsung oleh Koordinator Announcer, Program Director dan Kepala Seksi Programa 1.Program Director berkoordinasi langsung dengan Koordinator Announcer untuk menyusun materi acara setiap Day Part dan juga setiap Segment acara siaran, dalam setiap Day Part akan dipilih Penyiar yang sesuai dengan acara siaran tersebut. Program Director bertanggung jawab penuh atas penyusunan dan perencanaan acara siara, serta Koordinator Announcer juga 
turut serta untuk melakukan penjadwalan penyiar.Sama halnya dengan jadwal siaran, pengorganisasian narasumber dari siaran juga dilakukan oleh Kepala Seksi Programa

Untuk pengorganisasian sarana dan prasarana dibagi menjadi 2 (dua) bagian, yaitu bagian saran prasa prasarana kantor dan sarana prasarana penyiaran. sarana dan prasarana umum atau kantor diorganisasikan oleg bagian umum, baik kasubag ataupun stafnya. Sedangkan sarana dan prasarana penyiaran, dilakukan oleh bagian teknik, disini adalah kepala seksi teknik sarana dan prasarana penyiaran.

Subfokus 3 : Pelaksanaan Siaran Pendidikan Programa 1 (satu) RRI Pekanbaru

Pelaksanaan Tim Siaran Pendidikan dilakukan berdasarkan job description atau tugas dan wewenang dari staf RRI Pekanbaru.Berdasarkan dokumentasi dari peneliti, berikut adalah tabel Role and Responsibility Programa 1 Radio Republik Indonesia.

Tabel 5

Role and Responsibility Programa 1 (satu) Pekanbaru

\begin{tabular}{|c|c|c|}
\hline Jabatan & Role & $\begin{array}{c}\text { Tanggung } \\
\text { Jawab }\end{array}$ \\
\hline $\begin{array}{l}\text { Kepala Seksi } \\
\text { Programa }\end{array}$ & $\begin{array}{l}\text { Mengawasi } \\
\text { dan } \\
\text { merencanak } \\
\text { an kegiatan } \\
\text { siaran }\end{array}$ & $\begin{array}{l}\text { Bertanggung } \\
\text { jawab atas } \\
\text { keseluruhan } \\
\text { acara pada } \\
\text { Programa }\end{array}$ \\
\hline Administrasi & $\begin{array}{l}\text { Menangani } \\
\text { administrasi } \\
\text { siaran serta } \\
\text { membantu } \\
\text { kepala seksi } \\
\text { menyiapkan } \\
\text { laporan }\end{array}$ & $\begin{array}{l}\text { Bertanggung } \\
\text { jawab kepada } \\
\text { pelaksana } \\
\text { kegiatan } \\
\text { administrasi }\end{array}$ \\
\hline $\begin{array}{l}\text { Program } \\
\text { Director }\end{array}$ & $\begin{array}{l}\text { Merencanak } \\
\text { an serta } \\
\text { mengatur } \\
\text { atas jadwal } \\
\text { siaran radio }\end{array}$ & $\begin{array}{l}\text { Bertanggung } \\
\text { jawab pada } \\
\text { pelaksanaan } \\
\text { program } \\
\text { siaran pada } \\
\text { Programa }\end{array}$ \\
\hline $\begin{array}{l}\text { Music } \\
\text { Director }\end{array}$ & $\begin{array}{l}\text { Merencanak } \\
\text { an serta } \\
\text { mengatur } \\
\text { kebutuhan } \\
\text { music untuk } \\
\text { siaran Radio }\end{array}$ & $\begin{array}{l}\text { Bertanggung } \\
\text { jawab } \\
\text { terhadap } \\
\text { penyediaan } \\
\text { music serta } \\
\text { rotating music }\end{array}$ \\
\hline $\begin{array}{l}\text { Koordinator } \\
\text { Announcer }\end{array}$ & $\begin{array}{l}\text { Merencanak } \\
\text { an serta } \\
\text { mengatur } \\
\text { jadwal } \\
\text { penyiar }\end{array}$ & $\begin{array}{l}\text { Bertanggung } \\
\text { Jawab } \\
\text { terhadap } \\
\text { pelasana } \\
\text { siaran dan } \\
\text { jadwal } \\
\text { pelaksanaan } \\
\text { kegiatan } \\
\text { penyiaran }\end{array}$ \\
\hline Marketing & $\begin{array}{l}\text { Mengatur } \\
\text { serta } \\
\text { mencari } \\
\text { sponsor } \\
\text { untuk } \\
\text { kegiatan } \\
\text { penyiaran }\end{array}$ & $\begin{array}{l}\text { Bertanggung } \\
\text { jawab mencari } \\
\text { sponsor atau } \\
\text { iklan untuk } \\
\text { Programa }\end{array}$ \\
\hline $\begin{array}{l}\text { Penanggung } \\
\text { Jawab Teknik }\end{array}$ & $\begin{array}{l}\text { Merawaat } \\
\text { serta } \\
\text { merencanak } \\
\text { an } \\
\text { pengadaan } \\
\text { perangkat } \\
\text { teknik } \\
\text { penyiaran }\end{array}$ & $\begin{array}{l}\text { Bertanggung } \\
\text { jawab atas } \\
\text { keseluruhan } \\
\text { perangkat } \\
\text { teknik }\end{array}$ \\
\hline $\begin{array}{l}\text { Announcer } \\
\text { (Penyiar) }\end{array}$ & $\begin{array}{l}\text { Menyiarkan } \\
\text { acara serta } \\
\text { memandu } \\
\text { acara } \\
\text { penyiaran }\end{array}$ & $\begin{array}{l}\text { Bertanggung } \\
\text { jawab untuk } \\
\text { acara siaran } \\
\text { yang sedang } \\
\text { berlangsung }\end{array}$ \\
\hline
\end{tabular}


Untuk Pelaksanaan Program Siaran Pendidikan di Programa 1 (satu) Program harus sesuai dengan Peraturan KPI tentang Standar Program Siaran (P3).Berdasarkan observasi dari peneliti, pelaksanaan program siaran pendidikan di Programa 1 sudah sesuai dengan aturan yang berlaku.Untuk siaran pendidikan pra sekolah yang disiarkan setiap hari Senin sampai Jum'at pukul 16.00 s/d 17.00 sendiri tidak menayangkan iklan.

Setelah melakukan observasi, diketahui sarana dan prasarana diRRI Pekanbaru sudah memadai. Perawatan Sarana dan prasarana seperti ruang Kepala LPP RRI, ruangan staf bidang, ruang penyiar , ruang siaran (studio), ruang rekaman, ruangan membuat berita, aula, WC, dan gudang setiap hari dilakukan oleh petugas kebersihan. Selain itu, staf yang berada pada masing-masing bidang juga menjaga kebersihan dan peralatan yang ada di ruangan, seperti radio yang ada di setiap ruangan.

Sedangkan untuk pengelolaan sarana peralatan yang ada di studio dan ruang rekaman adalah tugas dari teknikal.Teknikal bertanggung jawab dalam pengelolaan semua peralatan yang ada di RRI.

\section{Subfokus 4 : Pengawasan Siaran Pendidikan Programa 1 (satu) RRI Pekanbaru}

Berdasarkan hasil dokumentasi pada Peraturan Pemerintah Republik Indonesia Nomor 12 Tahun 2005 tentang Lembaga Penyiaran Publik RRI, terdapat Dewan Pengawas yang merupakan organ lembaga penyiaran publik yang berfungsi mewakili masyarakat, pemerintah, dan unsur lembaga penyiaran publik yang menjalankan tugas pengawasan untuk mencapai tujuan lembaga penyiaran publik. Dewan Pengawas ditetapkan oleh Presiden atas usul DPR RI.

Pengawasan program pendidikan diawasi oleh semua pihak yang terkait yaitu kepala bidang siaran, kepala seksi perencanaan dan evaluasi programa, serta kepala seksi masing-masing programa.Pengawasan program salah satunya diawasi melalui radio yang ada di setiap ruangan.Selain itu pendengar juga turut andil dalam mengawasi setiap siaran di RRI.Sedangkan untuk jadwal siaran dan narasumber di Programa 1 (satu), diawasi oleh Kepala Seksi Programa 1 (satu).

Untuk pengawasan sarana dan prasarana yang ada di seluruh RRI dilakukan oleh Kepala LPP RRI.Sedangkan untuk sarana di dalam studio diawasai oleh kepala seksi teknik studio dan media baru.Selain itu bagian studio juga diawasi oleh setiap kepala seksi programa.

\section{PEMBAHASAN HASIL TEMUAN}

Pada bagian ini, peneliti memaparkan pembahasan temuan-temuan penelitian yang diperoleh dari hasil wawancara, observasi dan telaah dokumen sebagaimana diutarakan pada bagian sebelumnya.Pembahasan dalam penelitian ini adalah untuk menganalisis manajemen siaran pendidika Radio Republik Indonesia Pekanbaru pada programa 1 (satu).

\section{Subfokus 1 :Perencanaan Siaran Pendidikan di Programa 1(satu) RRI Pekanbaru}

Dalam dunia penyiaran, perencanaan merupakan unsur yang sangat penting, karena siaran memiliki dampak yang luas di masyarakat. Perencanaan yang dimaksud disini adalah perencanaan siaran termasuk di dalamnya perencanaan produksi dan pengadaan materi siaran, serta menyusunnya menjadi rangkaian mata acara, baik harian, mingguan, bulanan dan seterusnya sesuai dengan misi, fungsi, tugas dan tujuan yang hendak dicapai.

Perencanaan Program Siaran Pendidikan juga sudah sesuai dengan Peraturan Pemerintah.LPP RRI harus mengambil peran dalam membangun masyarakat yang berdaya saing dan berkarakter melalui siaran-siaran yang dapat membangkitkan masyarakat untuk mencipta, berkarya dan berproduksi melalui program-program Pendidikan. Program pendidikan juga disusun sesuai dengan misi organisasi yaitu siaran pendidikan untuk mencerahkan, mencerdaskan, dan memberdayakan serta mendorong kreatifitas masyarakat dalam kerangkan membangun karakter bangsa.Contoh siaran pendidikan untuk 
mencerahkan adalah pembacaan Al-Qur'an dan kuliah subuh. Pendidikan tidak hanya sebatas rumus dan angka, tapi pendidikan agama merupakan tiang dari semua pendidikan.

Disamping itu, dalam merencanakan program siaran pendidikan, seluruh staf yang terlibat akan ikut dalam Rapat program tahunan untuk membahas rencana program satu tahun disertai dengan susunan jadwal siaran pendidikan. Jadwal siaran pendidikan ini juga harus sesuai dengan Pedoman Perilaku Penyiaran (P3) dan Standard Program Siaran (SPS) oleh Komisi Penyiaran Indonesia Tahun 2012.

Selain rapat program tahunan, RRI Pekanbaru juga mengadakan rapat per 6 (enam) bulan sekali untuk melakukan evaluasi terhadap siaran yang sudah dijalankan. Jika ada siaran yang kurang kompeten, maka siaran tersebut akan dihapuskan.

Dari perencanaan siaran diatas dapat disimpulkan bahwa RRI telah menjalankan perencanaan siaran dengan baik sesuai dengan pendapat Morison (2011) yang menyatakan bahwa perencanaan siaran harus mempunyai variabel-variabel yang harus dipertimbangkan, yaitu:

1) Idealisme, merupakan visi dan misi dari lembaga penyiaran tersebut diperasionalkan dalam tujuan penyiaran.

2) Orientasi bisnis yang mengacu pada program-program atau acara-acara yang mempunyai rating tinggi.

3) Orientasi khalayak adalah mencakup kebutuhan khalayak dan keinginan khalayak. Dari ketiga poin diatas dapat dilihat program siaran yang dibuat oleh RRI didasarkan pada visi dan misi RRI.Disini pendidikan berperan sebagai pembangun karakter bangsa.Program siaran dibuat juga berdasarkan orientasi khalayak, yaitu mencakup kebutuhan (informasi) dan keinginan (entertainment).Contoh program Jelita yang tayang setiap hari merupakan sebuah informasi untuk khalayak.

Perencanaan sarana prasarana juga merupakan hal yang penting demi tercapainya tujuan penyiaran, terutama untuk sarana prasarana dalam teknikal.Jika salah satu tidak ada atau mengalami kerusakan, maka suatu siaran bisa menjadi tidak sempurna bahkan tidak dapat mengudara. Bagian teknikal terutama bagian teknik sarana dan prasarana penyiaran yang bertanggung jawab dalam hal menjaga peralatan yang ada di studio. Biasanya mereka melakukan service beberapa bulan sekali untuk tetap menjaga peralatan studio.

\section{Subfokus 2 :Pengorganisasian Siaran Pendidikan Programa 1 (satu) RRI Pekanbaru}

Menurut Morisan (2008) terdapat 2 (dua) aspek utama proses penyusunan struktur organisasi yaitu departementalisasi dan pembagian kerja. Departementalisasi merupakan pengelompokan kegiatan-kegiatan kerja suatu organisasi agar kegiatan yang sejenis dan saling berhubungan dapat dikerjakan bersama. Berdasarkan dokumentasi, observasi, dan wawancara pengorganisasian tim RRI dilakukan berdasarkan Peraturan Pemerintah Republik Indonesia Nomor 12 Tahun 2015 tentang Lembaga Penyiaran Publik Radio Republik Indonesia, didapati bahwa organisasi RRI terdiri dari Dewan Pengawas, Dewan Direksi, Stasiun penyiaran, Satuan pengawasan intern, serta pusat dan perwakilan. Satuan organisasi diatas, kecuali Dewan Pengawas, diatur lebih lanjut oleh dewan direksi.Sedangkan pengawas ditetapkan oleh Presiden atas usul DPR RI setelah melalui uji kepatutan dan kelayakan oleh DPR RI.

Radio Republik Indonesia Pekanbaru dipimpin oleh Kepala LPP RRI Pekanbaru.Selanjutnya ada kepala bagian tata usaha, kepala bidang program siaran, kepala bidang pemberitaan, kepala bidang teknologi dan media baru serta kepala bidang layanan dan pengembangan usaha yang dibawah langsung oleh kepala stasiun. Setiap staf RRI mempunyai SK dan surat pernyataan.

Dalam tugas penyiaran siaran pendidikan di Programa 1(satu) Pekanbaru dipimpin oleh kepala seksi programa 1(satu). Salah satu diantara tugas Kepala seksi programa 1(satu) adalah bertanggung jawab atas keberlangsungan 
siaran pada waktu dinas kepada kepala bidang. Kepala seksi programa 1 (satu) juga bertugas untuk mengkondisikan tugas-tugas penyiar programa 1 (satu).Dalam pengorganisasian program siaran pendidikan, dilaksanakan oleh kepala bidang program siaran dan juga bagian perencanaan dan evaluasi programa.Tetapi dalam hal ini yang lebih berperan adalah bagian perencanaan dan evaluasi programa.

Pengorganisasian sarana dan prasarana RRI Pekanbaru telah diatur oleh Kepala LPP RRI Pekanbaru.Untuk sarana dan prasarana RRI Pekanbaru dibagi menjadi 2 (dua) bagian, yaitu umum dan bagian studio. Sarana dan prasarana umum atau kantor diorganisasikan oleh bagian umum, baik kasubag ataupun stafnya. Sedangkan yang kedua adalah sarana dan prasarana penyiaran, dilakukan oleh bagian teknik, disini adalah kepala seksi teknik sarana dan prasarana penyiaran.

\section{Subfokus 3 : Pelaksanaan Siaran Pendidikan Programa 1 (satu) RRI Pekanbaru}

Pelaksanaan tim siaran pendidikan di Programa 1 (satu) dilakukan berdasarkan uraian tugas atau job description yang telah diatur oleh Kepala LPP RRI Pekanbaru. Dokumentasi uraian tugas ini disimpan oleh Kepala Sub Bagian SDM.Kepala Seksi mempunyai tanggung jawab atas keseluruhan acara pada programa.Kepala Seksi juga bertugas menyiapakna bahan referensi dan pendukung bagi pelaksanaan acara siaran. Di dalam programa 1 (satu) juga terdapat bagianbagian lainnya yaitu administrasi, program director, music director,koordinator announcer, marketing, penanggung jawab teknik, dan penyiar untuk melaksanakan siaran pendidikan. Kepala Seksi Programa 1 (satu) yang bertugas untuk mengkondisikan tugas-tugas penyiar di Programa 1 (Satu). Tugas Kepala Seksi Programa 1 (satu) mengatur seluruh kegiatan yang ada di programa 1 (satu) ini sesuai dengan pendapat tentang kepemimpinan oleh Abdulsyani (1987) yang berpendapat bahwa kepemimpinan adalah suatu proses pemberian pengaruh dan pengarahan dari seorang pemimpin terhadap orang lain (atau sekelompok orang) untuk melakukan suatu aktifitas tertentu yang sesuai kehendaknya.

Sebagai Radio yang bernaung di bawah pemerintahan, RRI Pekanbaru harus mematuhi peraturan-peraturan dalam melaksanakan program siaran radio, yang di penelitian ini adalah program siaran pendidikan.Peraturan yang harus diikuti salah satunya adalah peraturan pemerintah RI Nomor 12 Tahun 2005 tentang Lembaga Penyiaran Publik RRI dan Peraturan KPI tentang Pedoman Perilaku Penyiaran (P3).Programa 1 (satu) merupakan programa siaran RRI yang sasarannya adalah khalayak umum.Siaran pendidikannya dimulai untuk anak pra sekolah maupun dewasa.Setiap program siaran pendidikan yang disiarkan mempunyai peraturanperaturan sendiri yang harus diikuti, terutama ketika sedang menayangkan program siaran pendidikan untuk anak.

Radio Republik Indonesia (RRI) Pekanbaru membuat beberapa program untuk menarik minat pendengar radio khususnya anak-anak. Membawa langsung siswa-siswi untuk terlibat langsung dalam siaran langsung ataupun rekaman, contohnya adalah program siaran sahabat cilik untuk anak pra sekolah.Sahabat cilik adalah program siaran pendidikan untuk anak pra sekolah yang di dalamnya terdapat hiburan seperti nyanyian, pembacaan puisi dan lainnya.Pekan Tilawatil Qur'an oleh RRI juga merupakan salah satu pelaksanaan program siaran yang menarik minat pendengar untuk mendengarkan RRI Pekanbaru,

Pemanggilan narasumber sendiri harus dilaksanakan 1 (satu) bulan sebelum disiarkan. Hal ini dilakukan dengan alasan agar memiliki waktu yang cukup untuk mengatur jadwal rekaman siaran antara narasumber dengan studio yang akan dipakai rekaman.

\section{Subfokus 4 : Pengawasan Siaran Pendidikan Programa 1 (satu) RRI Pekanbaru}

Setelah semua proses perencanaan, pengorganisasian, dan pelaksanaan maka tahapan yang terakhir adalah pengawasan. Jabatan tertinggi di Radio Republik Indonesia 
(RRI) adalah Dewan Pengawas.Dewan pengawas berperan untuk menjalankan tugas pengawasan untuk mencapai tujuan lembaga penyiaran publik. Dewan pengawas yang melakukan pengawasan terhadap seluruh RRI di Indonesia.Terdapat juga Satuan Pengawasan Intern yang berfungsi melakukan pengawasan terhadap administrasi, keuangan, dan operasional di dalam lembaga penyiaran publik atau seluruh RRI di Indonesia.Satuan pengawasan intern dipimpin oleh seorang kepala yang kedudukannya berada di bawah dan bertanggung jawab kepada dewan direksi.

Setiap daerah mempunyai RRI atau biasanya disebut dengan satker (satuan kerja).Langkah pengawasan terhadap program siaran pendidikan dilakukan oleh semua pihak yang terkait terhadap jalannya program siaran terutama kepala bidang program siaran. Kepala Bidang Program Siaran bertugas untuk memantau siaran seluruh programa dan memantau penyusunan deskripsi acara siaran seluruh programa.

Selain itu, kepala seksi perencanaan dan evaluasi programa juga turut andil dalam memonitor siaran seluruh programa.Kepala seksi perencanaan dan evaluasi programa juga melakukan evaluasi pelaksanaan acara tiap tahunnya.Evaluasi terhadap program siaran, apakah siaran terlaksana dengan baik, juga dilakukan oleh bidang ini melalui DAS (Daftar Acara Siaran).

Kepala Seksi Programa 1 (satu) mempunyai tugas untuk melakukan pengawasa terhadap program acara yang sedang atau telah berlangsung di Programa 1 (Satu).Kepala Seksi Programa 1 (satu) juga bertugas untuk melakukan pengawasan terhadap jadwal siaran, penyiar, dan juga narasumber di Programa 1 (Satu).Keterlibatan pendengar juga bisa dijadikan alat pengawasan, karena pendengar juga secara langsung ikut menjalankan tugas pengawasan melalui siaran yang didengarnya.

Pengawasan terhadap sarana dan prasarana juga penting dilakukan, terutama terhadap bagian teknikal. Jika saran dan prasarana di bagian teknikal ini rusak, maka akan berpengaruh besar terhadap sebuah siaran. Adanya pengawasan terhadap sarana dan prasarana ini sejalan dengan pendapat JB Wahyudi (2008) yang mengatakan bahwa di dalam dunia penyiaran terdapat 2 (dua) hal yang harus dilakukan pengawasan yaitu penggunaan perangkat keras dan perangkat lunak.Perangkat keras adalah transmisi/ pemancar dan sarana prasarana.Sedangkan perangkat lunak adalah manusia pengelola, peraturan-peraturan, dan program.

\section{SIMPULAN DAN SARAN}

\section{Simpulan}

Data dari hasil penelitian ini dapat disimpulkan sebagai berikut:

1. Pada siaran pendidikan di Programa 1 (satu) RRI Pekanbaru yang merupakan langkah awal perencanaan adalah melalui rapat program yang dilaksanakan setiap tahun untuk membuat program pendidikan. Selanjutnya menentukan tim siaran pendidikan, penyiar, tema pendidikan, jadwal siaran dan narasumber. Narasumber dipilih dengan seksama yang dapat memberikan informasi yang akurat. Perencanaan di bagian teknik studio dilakukan secara matrang dengan cara memberikan panduan berupa lookbook yang diberikan kepada penyiar sebagai pedoman pada saat siaran. Semua perencanaan diatas juga disesuaikan dengan peraturan yang berlaku yaitu Peraturan Pemerintah Republik Indonesia Nomor 12 Tahun 2015 tentang Lembaga Penyiaran Publik Radio Republik Indonesia.

2. Pengorganisasian siaran pendidikan di Programa 1(satu) RRI Pekanbaru dilakukan dengan membentuk Tim oleh Kepala LPP RRI Pekanbaruyang direncanakan pada saat rapat program tahunan atau telah sesuai dengan SK masing-masing jika berstatus PNS dan diberikan wewenang dengan uraian tugas yang jelas.

3. Pelaksanaan siaran pendidikan di Programa 1 (satu) RRI Pekanbarusudah dilaksanakan berdasarkan Peraturan Pemerintah Republik Indonesia Nomor 12 Tahun 2015 tentang 
Lembaga Penyiaran Publik Radio Republik Indonesia serta peraturan KPI tentang Pedoman Perilaku Penyiaran (P3) tahun 2012. Selain itu, RRI juga melaksanakan event tahunan seperti Pekan Tilawatil Qur'an dan mengundang anak-anak pra sekolah maupun sekolah untuk datang langsung ke RRI Pekanbaru. Hal ini dilaksanakan untuk menarik minat anakanak maupun orang dewasa untuk mendengarkan RRI.

4. Pengawasan di RRI seluruh Indonesia dilakukan oleh Dewan Pengawas yang merupakan jabatan tertinggi di RRI. Sedangkan pengawasan RRI Pekanbaru dilakukan oleh Kepala LPP RRI Pekanbaru. Untuk pengawasan program siaran dilakukan oleh kepala bidang program siaran bekerjasama denga kepala seksi perencanaan dan evaluasi programa sedangkan pengawasan jadwal siaran di Programa 1 (satu) Pekanbaru dilakukan oleh Kepala Seksi Programa 1 (satu).

\section{Saran}

Berdasarkan kesimpulan diatas dapat disimpulkan bahwa Manajemen Siaran Pendidikan di Programa 1 (satu) Radio Republik Indonesia (RRI) sudah berjalan baik, namun ada beberapa hal yang harus diperbaiki dalam manajemennya, adapun saran dari peneliti adalah sebagai berikut:

Pertama, dalam melakukan perencanaan, hendaklah dipertimbangkan topik yang lebih menarik dan beragam agar lebih menarik minat pendengar khususnya anak-anak untuk mendengarkan RRI Pekanbaru, karena program yang ditawarkan cenderung sama setiap tahun. Manajemen Siaran Pendidikan di RRI belum bisa merumuskan dan menjalankan program yang lebih menarik minat pendengar terutama anakanak.Event tahunan harus lebih diperbanyak selain Pekan Tilawatil Qur'an.

Kedua, dalam hal Pengawasan, agar lebih diperhatikan koreksi - koreksi yang diberikan baik dari tim produksi maupun dari pendengar dan diadakannya penilaian melalui rating resmi untuk menilai RRI Pekanbaru agar program siaran di RRI Pekanbaru juga dapat lebih ditingkatkan lagi.

\section{DAFTAR PUSTAKA}

Abdul Syani. 1987. Manajemen Organisasi. Jakarta : Penerbit PT. Bina Aksara

Al Muchtar S. 2000. Epistemologi Pendidikan Ilmu Pengetahuan Sosial. Bandung: Gelar Pustaka Mandiri

Asep Syamsul M.Romli. 2009. Dasar-Dasar Siaran Radio. Bandung: Nuansa

Daft, Richard L., 2010. Era Baru Manajemen. Terjemahan oleh Tita Maria Kanita. Edisi kesembilan. Jakarta: Penerbit Salemba

Darmanto Antonius. 1998. Teknik Penulisan Naskah Acara Siaran Radio. Yogyakata: Universitas Atmajaya.

Onong Uchjana Effendy. 2003. Ilmu, Teori, dan Filsafat Komunikasi. Bandung: PT. Citra Aditya Bakti

Fred Wibowo. 2011. Teknik Produksi Program Radio Siaran. Yogyakarta : Grasia Book Publisher.

J.B Wahyudi. 2008. Dasar-Dasar Manajemen Penyiaran. Jakarta :PT.Gramedia Pustaka Utama

Hidajanto Djamal \& Andi F. 2011. Dasar-dasar Penyiaran. Jakarta: Kencana

Innayah. 2014. Model Evaluasi Siaran Radio Edukasi dari Radio Mitra Hingga Pendengar. Jurnal Kependidikan, Vol.11 No.1

Ishadi SK. 1999. Dunia Penyiaran: Prospek dan Tantangaanya. Jakarta: PT.Gramedia Pustaka Utama

Malayu Hasibuan. 2007. Organisasi dan Motivasi. Jakarta: Sinar Grafika Offset

.2014. Manajemen : Dasar, Pengertian, dan Masalah. Cetakan ke sepuluh. Jakarta: Bumi Aksara

Marulli J.Indarto. 2012. Manajemen Komunikasi. Tesis pascasarjana Universitas Indonesia. Jakarta

Moeryani Ginting Munthe. 1996. Media Komunikasi Radio. Jakarta: Pustaka Sinar Harapan 
Morissan. 2005. Manajemen Penyiaran Strategi Mengelola Radio dan Televisi. Jakarta: Kencana

.2008. Manajemen Media Penyiaran. Jakarta: Kencana Prenada Media

.2011. Manajemen Media Penyiaran: Strategi Mengelola Radio dan Televisi. Jakarta :Kencana Prenada Media.

Prayuda Herley. 2005. Radio : Suatu Pengantar Untuk Wacana dan Praktek Penyiaran. Malang: Bayu Media

Rhenald Kasali. 1999. Manajemen Public Relations. Jakarta:Penerbit Grafiti.

Rotler, Philip., 2000. Manajemen Pemasaran. Jakarta: PT.Prenhallindo.

Ruth Debora Massie. 2013. Manajemen Program Siaran Radio Interaktif di Kantor RRI Manado. dalam Journal Acta Diurna Universitas Sam Ratulangi, Vol.11 No.3
Sanusi Hartinah, Djabir Hamzah \& Andi Alimuddin Unde., 2010, Manajemen Media Televisi Fajar TV : Antara Bisnis dan Idealisme, dalam Jurnal Komunikasi di unduh pada tanggal 15 Agustus 2016 melalui http://pasca.unhas.ac.id/jurnal/files/ Sondang P.Siagan. 1992. Fungsi-Fungsi Manajerial. Jakarta: Bumi Aksara

Suharsimi Arikunto. 2010. Prosedur Penelitian Suatu Pendekatan Praktek. Edisi Revisi. Jakarta: Rineka Cipta

Suwardi Handayaningrat. 2011. Pengantar Studi Administrasi dan Manajemen. Jakarta:Gunung Agung.

R.Terry,George., 2005. Dasar-Dasar Manajemen. Cetakan kesembilan. Jakarta: Bumi Aksara.

Triyono. 2013. Metode Penelitian Pendidikan. Yogyakarta: Penerbit Ombak 